\title{
КОНЦЕНТРАЦИЯ КОРТИЗОЛА \\ В МЫШЕЧНОЙ ТКАНИ МОДЕЛЬНОГО ОРГАНИЗМА DANIO RERIO ПОСЛЕ СТРЕССОВОГО ВОЗДЕЙСТВИЯ И ВВЕДЕНИЯ АНАТГОНИСТОВ ГРЕЛИНА
}

\author{
А.А. Блаженко, П. Хохлов, Э.Р. Бычков, А.С. Девяшин, А.А. Лебедев, \\ С. Прошин, П.Д. Шабанов
}

Отдел нейрофармакологии им. С.В.Аничкова, ФГБНУ ИЭМ, 197376, Россия, Санкт-Петербург, ул. Павлова 12.

DOI: 10.19163/MedChemRussia2021-2021-349

Согласно литературным данным кортизол является биомаркером стресса также у D. rerio. Методы. B нашем исследовании было использовано 68 моделей Danio rerio, один хищник Cichlasoma nicaraguensis. Рыб содержали при нормальной комнатной температуре $\left(22-23^{\circ} \mathrm{C}\right)$ со стандартным временем кормления (два раза в день). Уровень кортизола проверяли тестом ELISA. Хирургическим путем выполнен забор хвостовой мышцы D.rerio. После этого был изготовлен материал для ИФА. Результаты и обсуждение. В контрольной группе (интактная рыба) уровень кортизола составил 0,346 $\pm 0,035 \mathrm{Hг} \mathrm{/} \mathrm{мг}$ белка. После воздействия хищником его уровень изменился до 0,720 $\pm 0,052$ нг / мг белка. После введения CRF интактной рыбе уровень кортизола составил 0,896 0 0,068 нг / мг белка. После введения [D-Lys3] -GHRP-6 интактной рыбе уровень кортизола составил 0,356 $\pm 0,043$. А после введения [D-Lys3] -GHRP-6 и воздействия хищником уровень кортизола изменился до 0,357 $\pm 0,029$ нг / мг белка. Уровень кортизола после воздействия CRF составил 0,896 +/- 0,068 нг / мг белка. Заключение. Воздействие хищника увеличивало уровень кортизола в хвостовой мышце D.rerio практически вдвое. Антагонист грелина [D-Lys3] - GHRP-6 существенно не изменял уровень кортизола у интактной рыбы, но снижал уровень кортизола, который был повышен при контакте с хищником.

\section{Литература}

[1] Spencer S.J. и др. Ghrelin's role in the hypothalamic-pituitary-adrenal axis stress response: Implications for mood disorders // Biol. Psychiatry. 2015. T. 78. № 1. C. 19-27. 